\title{
Pemenuhan Hak Rekreasional Terhadap Narapidana Anak Di Lembaga Pembinaan Khusus Anak Banda Aceh
}

\author{
Zulyani Mahmud, Zahratul Idami dan Suhaimi \\ zulyanimahmud@gmail.com \\ Universitas Syiah Kuala, Aceh
}

\begin{abstract}
Keywords: $\quad$ Abstract
Fullfillment; Right; This article discusses and describes the task of the Banda Aceh Special Development Recreational; Child Institute (LPKA) in providing guidance and fulfilling the rights of children in lpka. Law Prisioner. No. 11 of 2012 on the child criminal justice system in Article 3 states that every child in the criminal justice process has the right to conduct recreational activities, but in fact the fulfillment of children's recreational rights has not been carried out to the maximum while in LPKA. The research method used is empirical juridical research method. The results showed the granting of Recreational Rights has not been running optimally, from within the LPKA is done by giving a schedule of play to students on holidays, activities carried out are playing volleys and playing musical instruments, activities outside lpka is to be a guest at discussion events held by other parties. not clearly regulated how the granting of recreational rights, the granting of recreational rights is done only on the basis of the policy of the Head of LPKA. Inhibitory factors in the absence of a special budget for the granting of recreational rights.
\end{abstract}

\section{Kata Kunci: $\quad$ Abstrak}

Pemenuhan; Hak; Artikel ini membahas dan menganilis tugas Lembaga Pembinaan Khusus Anak Rekreasional; (LPKA) Banda Aceh dalam memberikan pembinaan dan mempenuhi hak-hak Narapidana Anak. anak di dalam LPKA, Undang-Undang Nomor 11 Tahun 2012 tentang sistem peradilan pidana anak dalam Pasal 3 menyebutkan bahwa setiap anak dalam proses peradilan pidana berhak melakukan kegiatan rekreasional, Namun dalam faktanya pemenuhan hak rekreasional anak belumlah terlaksana dengan maksimal selama di LPKA. Metode penelitian yang digunakan adalah metode penelitian yuridis empiris. Hasil penelitian menunjukan pemberian Hak Rekreasional belum berjalan maksimal, dari dalam LPKA dilakukan dengan cara memberikan jadwal bermain kepada anak didik di hari libur, kegiatan yang dilakukan adalah bermain volley dan bermain alat musik, kegiatan di luar LPKA yaitu menjadi tamu pada acaraacara diskusi yang di selenggarkan pihak lain. tidak diatur secara jelas bagaimana pemberian hak rekreasional tersebut, pemberian hak rekreasional dilakukan hanya atas dasar kebijakan Kepala LPKA. Faktor Penghambat tidak adanya anggaran khusus untuk pemberian hak rekreasional.

Copyright (c) 2021 Zulyani Mahmud, Zahratul Idami dan Suhaimi. Published in Media Iuris. Published by Universitas Airlangga, Magister Ilmu Hukum.

\section{Pendahuluan}

Indonesia adalah negara hukum yang demokratis dan konstitusional, yaitu negara demokrasi yang berdasar atas hukum dan konstitusi. Hal ini tercermin dalam ketentuan Pasal 1 Ayat (2) dan (3) Undang-Undang Dasar Negara 
Zulyani Mahmud, dkk: Pemenuhan Hak Rekreasional...

Republik Indonesia Tahun 1945 (UUD NRI 1945). Indonesia sebagai negara yang menempatkan konstitusi sebagai hukum tertinggi, menimbulkan konsekuensi bahwa negara harus menyediakan mekanisme yang menjamin ketentuanketentuan konstitusi dilaksanakan dalam praktik kehidupan bermasyarakat, berbangsa dan bernegara. ${ }^{1}$

Negara Republik Indonesia adalah Negara Hukum berdasarkan Pancasila dan Undang-Undang Dasar Negara Republik Indonesia Tahun 1945. Salah satu ciri negara hukum adalah mengakui dan menjungjung tinggi Hak Asasi Manusia bukan hanya diperoleh oleh orang dewasa namun anak-anak juga berhak memperolehnya. ${ }^{2}$

Anak adalah anugerah Tuhan"sebagai bagian dari generasi muda yang juga merupakan aset bangsa, anak mempunyai peran strategis dalam pembangunan bangsa termasuk pembangunan nasional, eksistensi anak ini juga di atur dalam Undang-Undang Dasar Negara Republik Indonesia Tahun 1945, maka dengan itu" dapat diartiakn bahwa pemerintah sangat mempedulikan hak-hak anak serta juga memberikan perlindungan dasar kepada anak. ${ }^{3}$

Secara yuridis, usaha pemberian perlindungan hak-hak anak oleh dunia internasional sudah dimulai sejak Deklarasi PBB Tahun 1959 tentang Hak-Hak Anak, dan terakhir Konvensi Hak Anak (Convention of the Rights of the Child) tahun 1989 tanggal 5 Desember 1989. Konvensi ini berisi tentang Penegasan Hak-Hak Anak. Perlindungan anak oleh negara dan peran serta berbagai pihak (negara, masyarakat, dan swasta) dalam menjamin perlindungan hak-hak anak, melindungi dan mengayomi anak yang berhadapan dengan hukum agar anak dapat menyongsong masa depannya yang masih panjang serta memberi kesempatan kepada anak agar melalui pembinaan akan diperoleh jati dirinya untuk menjadi manusia yang mandiri, bertanggung jawab dan berguna bagi diri sendiri, keluarga, masyarakat,

\footnotetext{
${ }^{1}$ Pasal 1 ayat (2) UUD NRI 1945 menyatakan bahwa, "Kedaulatan berada di tangan rakyat dan dilaksanakan menurut Undang-Undang Dasar".

${ }^{2}$ Hartono Hartono, 'Konsep Pembinaan Anak Dalam Lembaga Pembinaan Khusus Anak (LPKA) Dalam Perspektif Hak Asasi Manusia' (2019) 11 (1) YURJSKA Jurnal Ilmiah Hukum.[75].

${ }^{3}$ Budijanto, 'Pemenuhan Hak Pendidikan Bagi Anak Didik Pemasyarakatan Di Lembaga Pembinaan Khusus Anak’ (2013) 7 (1) Jurnal Ilmiah Kebijakan Hukum.[64]
} 
bangsa, dan negara adalah tujuan dari Peradilan Pidana Anak yang disebutkan dalam UU No. 3 Tahun 1997 tentang Pengadilan Anak. ${ }^{4}$

Peradilan bagi anakyang melakukan kejahatan bukanlah bertujuan untuk menghukum tetapi untuk memberikan kepentingan yang terbaik kepada anak (the best interests of the child). Hal ini merupakan prinsip yang seharusnya melandasi dalam setiap kebijakan dan tindakan yang dilakukan oleh siapapun, sebagaimana termaktub dalam Pasal 3 Konvensi Hak Anak bahwa, dalam semua tindakan yang menyangkut anak-anak, baik yang dilakukan lembaga-lembaga kesejahteraan sosial pemerintah atau swasta, pengadilan, para penguasa pemerintahan atau badan legislatif, kepentingan terbaik harus menjadi pertimbangan utama. ${ }^{5}$

Selanjutnya dalam hal melindungi hak-hak anak yaitu Undang-Undang Nomor 39 Tahun 1999 Tentang Hak Asasi Manusia. Pada bagian kesepuluh Pasal 52 ayat (1) disebutkan: "setiap anak berhak atas perlindungan oleh orang tua, keluarga, masyarakat dan negara". Selanjutnya dalam ayat (2) disebutkan: "hak anak adalah hak asasi manusia dan hak untuk kepentingannya itu diakui dan dilindungi oleh hukum bahkan sejak dalam kandungan. Oleh karena itu secara konsepsi anak berhadapan dengan hukum tetap harus dipenuhi setiap hak-haknya.

Di dalam penjelasan Undang-Undang Nomor 35 Tahun 2014 Tentang Perlindungan Anak juga disebutkan bahwa "Negara, pemerintah, pemerintah daerah, masyarakat, keluarga dan orang tua berkewajiban untuk memberikan perlindungan dan menjamin terpenuhinya hak asasi anak sesuai dengan tugas dan tanggung jawabnya.

Anak yang dilakukan penahanan ditempatkan di Lembaga Penempatan Anak Sementara (LPAS). Dalam masa penahanan di LPAS Anak berhak memperoleh pelayanan, perawatan, pendidikan dan pelatihan, pembimbingan dan pendampingan serta hak lain sesuai dengan peraturan perundang- undangan. Dengan demikian LPAS wajib menyelenggarakan pendidikan, pelatihan keterampilan, dan pemenuhan hak lain sesuai peraturan perundang-undangan.

\footnotetext{
${ }^{4}$ R.Wiyono, Sistem Peradilan Pidana Anak di Indonesia (Sinar Grafika 2019).[7].

${ }^{5}$ Wagiati soetedjo dan Melani, Hukum Pidana Anak (Refika Aditama 2017).[53].
} 
Zulyani Mahmud, dkk: Pemenuhan Hak Rekreasional...

Pembimbing Kemasyarakatan melakukan penelitian kemasyarakatan untuk menentukan penyelenggaraan program pendidikan. Bapas wajib melakukan pengawasan terhadap pelaksanaan program.

Pendidikan merupakan suatu modal yang sangat penting bagi manusia terutama untuk penerus bangsa, jika anak-anak bangsa ini mendapatkan pendidikan yang baik maka anak-anak bangsa ini bisa membangun bangsa ini dengan baik kedepannya, kemudian dalam Pasal 31 Ayat 1 Undang-Undang Dasar 1945 menyatakan setiap warga negara berhak mendapatkan pendidikan dan kemudian juga dalam Pasal 31 Ayat 2 Undang-Undang Dasar 1945 disebutkan bahwa warga negara wajib mengikuti pendidikan dasar dan pemerintah membiayinya, pemberian hak untuk mendapatkan pendidikan ini juga harus didapatkan oleh anak didik di LPKA. ${ }^{6}$

Masa anak usia dini merupakan masa keemasan atau sering disebut Golden Age. Pada masa ini otak anak mengalami perkembangan paling cepat sepanjang sejarah kehidupannya. Hal ini berlangsung pada saat anak dalam kandungan hingga usia dini, yaitu usia nol sampai enam tahun. Namun, masa bayi dalam kandungan hingga lahir, sampai usia empat tahun adalah masa-masa yang paling menentukan. Periode ini, otak anak sedang mengalami pertumbuhan yang sangat pesat. Oleh karena itu memberikan perhatian lebih terhadap anak di usia dini merupakan keniscayaan. Wujud perhatian diantaranya dengan memberikan pendidikan baik langsung dari orang tuanya sendiri maupun melalui lembaga Pendidikan anak usia dini. ${ }^{7}$

Undang-Undang Nomor 11 Tahun 2012 tentang sistem peradilan pidana anak dalam Pasal 3 menyebutkan bahwa setiap anak dalam proses peradilan pidana berhak:

a. diperlakukan secara manusiawi dengan memperhatikan kebutuhan sesuai

\footnotetext{
${ }^{6}$ Riska Wiraman dan Ida Hayu Dwimawanti. ‘Kualitas Pelayanan Pendidikan Anak Binaan di Lembaga Pembinaan Khusus Anak (LPKA) Klas 1 Kutoarjo Kabupaten Purworejo' (2019) 1 (2) Jurnal Ilmu Administrasi Publik.[15].

${ }^{7}$ Moh Fauziddin dan Mufarizuddin 'Useful Of Clap Hand Games For Optimalize Cogtivitie Aspects In Early Childhood Education' (2018) 2 (2) Jurnal Obsesi: Jurnal Pendidikan Anak Usia Dini.[163].
} 
dengan umurnya;

b. dipisahkan dari orang dewasa;

c. memperoleh bantuan hukum dan bantuan lain secara efektif;

d. melakukan kegiatan rekreasional;

e. bebas dari penyiksaan, penghukuman atau perlakuan lain yang kejam, tidak manusiawi, serta merendahkan derajat dan martabatnya;

f. tidak dijatuhi pidana mati atau pidana seumur hidup;

g. tidak ditangkap, ditahan, atau dipenjara, kecuali sebagai upaya terakhir dan dalam waktu yang paling singkat;

h. memperoleh keadilan di muka pengadilan Anak yang objektif, tidak memihak, dan dalam sidang yang tertutup untuk umum;

i. tidak dipublikasikan identitasnya;

j. memperoleh pendampingan orang tua/Wali dan orang yang dipercaya oleh Anak;

k. memperoleh advokasi sosial,

1. memperoleh kehidupan pribadi,

m. memperoleh aksesibilitas, terutama bagi anak cacat

n. memperoleh pendidikan;

o. memperoleh pelayananan kesehatan: dan

p. memperoleh hak lain sesuai dengan ketentuan peraturan perundangundangan.

Dalam hal pembinaan anak narapidana menurut peraturan perundangundangan di Indonesia sudah ditempatkan di lembaga pemasyarakatan (lapas) khusus anak. Lembaga pemasyarakatan (lapas) anak telah berubah menjadi Lembaga pembinaan Khusus Anak (LPKA) adalah tempat pelaksanaan pidana penjara bagi anak hingga usia anak mencapai 18 (delapan belas) tahun. LPKA diwajibkan untuk menyelenggarakan pendidikan, pelatihan keterampilan, pembinaan dan pemenuhan hak lain sesuai dengan peraturan perundang-undangan. ${ }^{8}$

Pembinaan secara luas diartikan rangkaian upaya pengendalian secara proporsional terhadap semua unsur organisasi agar unsur-unsur tersebut dapat berfungsi sebagaimana mestinya sehingga rencana untuk mencapai tujuan dapat terlaksana secara berdaya dan berhasil guna. Program pembinaan di LPKA terdiri dari lima pembinaan yaitu pendidikan kesadaran agama, pendidikan kesadaran berbangsa dan bernegara, pendidikan kemampuan intelektual dan kecerdasan, pendidikan kesadaran hukum, yang terakhir

\footnotetext{
${ }^{8}$ Lilik Mulyadi, Wajah Sistem Peradilan Pidana Indonesia, (PT Alumni 2014) .[230].
} 
Zulyani Mahmud, dkk: Pemenuhan Hak Rekreasional...

pendidikan mengintegrasi diri dengan masyarakat. ${ }^{9}$

Keberadaan Undang-Undang Nomor 11 Tahun 2012 tentang Sistem Peradilan Pidana Anak (SPPA) memberikan suatu perubahan terhadap sistem penghukuman anak. Salah satu perubahannya adalah Lembaga Terhadap Pembinaan Yang Dikhususkan Kepada Anak(LPKA). Sesuai dengan diterapkan Undang-Undang ini paling tidak lamanya 3 (tiga)tahun, karena seorang anak yang dihukum ataupun dianggap telah melakukan kejahatanat aupun tindakan pidana, harus tetap berhak mendapatkan hak-haknya selama berada di Lembaga Pembinaan Khusus Anak (LPKA) tersebut. ${ }^{10}$

Banda Aceh merupakan salah satu daerah yang mempunyai Lembaga Pembinaan Khusus Anak (LPKA), terdapat 23 narapidana anak yang didik di LPKA Banda Aceh, dari 23 Anak ini mempunyai umur yang berbeda-beda, dengan perbedaan umur di antara mereka tentunya memerlukan hak rekreasional yang berbeda-beda juga, namun selama ini hak rekreasional yang di berikan di samaratakan, tidak diberikan hak rekreasional berdasarkan umur anak didik, kehadiran Lembaga Pembinaan Khusus Anak (LPKA) ini diharapkan dapat memberikan hak-hak anak yang ada di dalam menjalani masa pidananya, salah satunya yaitu hak rekreasional anak dan hak diperlakukan sebagaimana kebutuhannya. Sebagaimana yang disebutkan dalam Pasal 3 huruf a yaitu anak berhak diperlakukan secara manusiawi dengan memperhatikan kebutuhan sesuai dengan umurnya. Pasal 3 huruf d yaitu disebutkan anak berhak melakukan kegiatan rekreasional. Walaupun dirinya sedang menjalani masa hukuman penjara namun anak tetap harus dipenuhi haknya sesuai dengan aturan dalam undang-undang. LPKA Banda Aceh bertanggungjawab memberikan hak-hak kepada anak yang sedang menjalani masa hukumannya. Adapun hak anak didik pemasyarakatan (ANDIK PAS) di LPKA KELAS II Banda Aceh dalam pemenuhan

\footnotetext{
${ }^{9}$ Lili halimah, 'Representasi Civic Disposition melalui Pendekatan Moral pada Anak Didik Pemasyarakatan di Lembaga Pembinaan Khusus Anak (LPKA) Sukamiskin Provinsi Jawa Barat' (2020) 5 (1) Jurnal Pancasila dan Kewarganegaraan (JPK).[41].

${ }^{10}$ Sri Sutatiek (2013) Rekonstruksi Sistem Sanksi Dalam Hukum Pidana Anak Di Indonesia, (AswajaPressindo 2013).[24].
} 
hak rekreasional anak yaitu: Hak rekreasi dan bermain, seperti olah raga, nonton bersama, outbond, bermain musik, bermain bola kaki, mengunjungi perpustakaan, kegiatan menanam pohon dan budidaya ikan.

Pada tahun 2018 LPKA kelas II Banda Aceh juga pernah membawa Andik PAS ke Unsyiah dalam acara pemilihan Duta Baca Unsyiah tahun 2018, Anidik PAS juga berkesempatan untuk menampilkan tarian Didong. Pada bulan Juli 2019, 2 orang Andik PAS mengikuti kegiatan Jambore Pemasyarakatan di LPKA Tangerang.

LPKA Kelas II Banda Aceh juga pernah membawa Andik PAS ke ruang theater Perpustakaan Unsyiah guna memenuhi undangan Kepala UPT Perpustakaan Unsyiah sebanyak dua kali, yaitu: pada tanggal 20 Desember 2018 dengan agenda mengikuti kegiatan seminar motivasi yang disampaikan oleh Ibu Suraiya Kamaruzzaman selaku aktivis hak perempuan dan pemerhati Anak. Kegiatan ini juga diisi denga penampilan bakat seni Andik PAS serta Menggambar dan menonton bersama. Pada tanggal 25 Mei 2019 dengan agenda nonton bareng film bertemakan Islam yaitu The Message" tentang perjuangan Nabi Muhammad Saw menegakkan agama Allah. Namun di dalam faktanya pemenuhan hak rekreasional anak sesuai dengan data di atas belumlah terlaksana dengan maksimal. Dikarenakan selama ini tidak ada aturan khusus mengenai mekanisme pemberian hak rekreasional tersebut, pemberian hak rekreasional selama ini hanya sebatas dari kebijakan Kepala LPKA. Maka dengan tidak maksimalnya pemenuhan hak rekreasional terhadap anak di dalam lapas merupakan suatu permasalahan hukum terhadap implementasi/efektifnya hukum di dalam realita masyarakat. Sampai saat ini pemberian hak rekreasional anak masih terdapat beberapa hambatan, sehingga pemberian hak rekreasional anak di LPKA Banda Aceh belum maksimal.

\section{Metode Penelitian}

Metode Penelitian yang digunakan yaitu penelitian yuridis empiris, penelitian ini dipilih untuk mengetahui fakta yang terjadi di lapangan. Pendekatan yang digunakan adalah pendekatan konseptual. 
Zulyani Mahmud, dkk: Pemenuhan Hak Rekreasional...

Teknik pengumpulan data yang dilakukan pada penelitian ini yaitu melakukan wawancara di lapangan terhadap responden dan informan yang terkait dalam permasalahan, yang menjadi responden dalam penelitian ini adalah Kasi Adm. Pengawasan dan Penegakan Disiplin LPKA Banda Aceh (Susiyanti, A.Md) Kemudian Kasubsie Pendidikan dan Bimekemas LPKA Banda Aceh (Lutfi, S.H.) menjadikan mereka sebagai responden untuk mendapatkan informasi mengenai bagaimana pemberian hak rekreasional kepada anak didik di LPKA Banda Aceh selama ini, dari hasil wawancara responden ini juga bertujuan untuk mendapatkan informasi tentang hambatan dan upaya yang akan di lakukan oleh LPKA Banda Aceh dalam pemberian hak rekreasional kepada anakdidik di LPKA. Kemudian mewawancarai 3 orang anak didik di LPKA Banda Aceh ( Jauhar Nafis, Miki Syahputra, Ria Miranda) adalah bertujuan untuk mengetahui bagaimana pemberian hak rekreasional oleh LPKA kepada mereka selama di LPKA, mewawancarai anak didik LPKA ini bertujuan agar mengetahui fakta terkini dilapangan, kemudian di cocokan dengan data yang diberikan oleh pihak LPKA, wawancara dilakukan kepada 3 anak didik bertujuan mendapatkan informasi yang berbeda-beda, dengan 3 anak didik tersebut sudah bisa mewakili anak didik lainnya. kemudian yang menjadi informan dalam penelitian ini adalah ibu dari anak didik, mewawancari ibu dari anak didik ini untuk mengetahui sudut pandang dari seorang ibu tentang keluh kesah sang anak selama di LPKA, serta bertujuan mengetahui harapan dari ibu kepada anaknya yang berada di LPKA, kemudian mewawancarai Dosen Prodi Psikologi Universitas Syiah Kuala (Afriani, S.Psi.,M.Sc) untuk mengetahui masa pertumbuhan si anak, kapan anak membutuhkan hak rekreasional, kemudian mengetahui seberapa banyak kebutuhan hak rekreasional seharusnya yang perlu didapatkan oleh anak didik di LPKA berdasarkan teori-teori keilmuan. studi dokumen yang dilakukan untuk menghimpun data dengan melakukan penelaahan bahan-bahan kepustakaan yang meliputi bahan hukum primer, kemudian bahan hukum sekunder dan bahan hukum tersier. Dokumen ini merupakan sumber informasi yang penting yang berhubungan dengan Pelaksanaan pemenuhan hak rekreasional terhadap narapidana anak di LPKA Banda Aceh. 


\section{Pelaksanaan Pemenuhan Hak Rekreasional kepada Anak dalam Proses Pembinaan di Lembaga Pembinaan Khusus Anak Kota Banda Aceh}

Peradilan bagi anak yang melakukan kejahatan bukanlah bertujuan untuk menghukum tetapi untuk memberikan kepentingan yang terbaik kepada anak (the best interests of the child). Hal ini merupakan prinsip yang seharusnya melandasi dalam setiap kebijakan dan tindakan yang dilakukan oleh siapapun, sebagaimana termaktub dalam Pasal 3"Konvensi Hak Anak bahwa: "dalam semua tindakan yang menyangkut anak-anak, baik yang dilakukan lembaga-lembaga kesejahteraan sosial pemerintah atau swasta, pengadilan, para penguasa pemerintahan atau badan legislatif, kepentingan terbaik harus menjadi pertimbangan utama".

Anak yang Bermasalah dengan Hukum(ABH), kerapkali tidak mengerti dengan apa yang diperbuatnya, dan harus diarahkan serta diberikan bentuk pembinaan khusus terhadapnya. Diharapkan seorang anak yang bermasalah/ berkonflik terhadap hukum akan menjadi karakter yang berbentuk berdasarkan berbudi pekerti yang mulia dan luhur, dapat menunjukkan sikap sopan santun, tertib sesuai aturan dan adat yang ada dan memperlihatkan tingkah laku/ perbuatan yang beradap baik terhadap diri sendiri maupun terhadap masyarakat. ${ }^{11}$

Selanjutnya dalam hal melindungi hak-hak anak yaitu Undang-Undang Nomor 39 Tahun 1999 Tentang Hak Asasi Manusia. Pada bagian kesepuluh Pasal 52 ayat (1) disebutkan: "setiap anak berhak atas perlindungan oleh orang tua, keluarga, masyarakat dan negara". Selanjutnya dalam ayat (2) disebutkan: "hak anak adalah hak asasi manusia dan hak untuk kepentingannya itu diakui dan dilindungi oleh hukum bahkan sejak dalam kandungan. Oleh karena itu secara konsepsi anak berhadapan dengan hukum tetap harus dipenuhi setiap hak-haknya".

Dalam penjelasan Undang-UndangNomor35Tahun2014Tentang Perlindungan Anak juga disebutkan bahwa "Negara, pemerintah, pemerintah daerah, masyarakat, keluarga dan orang tua berkewajiban untuk memberikan perlindungan dan menjamin terpenuhinya hak asasi anak sesuai dengan tugas dan tanggung jawabnya.

${ }^{11}$ Fransiska Novita Eleanora, 'Tinjauan Yuridis Pembinaan Anak di Lembaga Pembinaan Khusus Anak (LPKA) Tangerang' (2018) 18 (3) Jurnal Kajian Ilmiah.[217]. 
Zulyani Mahmud, dkk: Pemenuhan Hak Rekreasional...

Anak yang dilakukan penahanan ditempatkan di LPAS (Lembaga Penempatan Anak Sementara). Dalam masa penahanan"di LPAS Anak berhak memperoleh pelayanan, perawatan, pendidikan dan pelatihan, pembimbingan dan pendampingan serta hak lain sesuai dengan peraturan perundang- undangan. Dengan demikian LPAS wajib menyelenggarakan pendidikan, pelatihan keterampilan, dan pemenuhan hak lain sesuai peraturan perundang-undangan. Pembimbing Kemasyarakatan melakukan penelitian kemasyarakatan untuk menentukan penyelenggaraan program pendidikan. Bapas wajib melakukan pengawasan terhadap pelaksanaan program.

Pendidikan tetap berhak diperolehpelaku anak dalam suatu proses peradilanterhadap pidana. Selain itu, kewajiban pelakuanak mengikuti seluruh pendidikan berupaformal (sekolah) dan/ataupun yang diadakanoleh pemerintah atau badan swasta barupa pelatihan atau tindakan yang dapatdiberikan/ dikenakan terhadap pelaku anaksesuai dengan amanat Undang-Undang SistemPeradilan Pidana Anak (UU-SPPA). ${ }^{12}$

Banda Aceh merupakan salah satu daerah yang mempunyai LPKA, terdapat 23 narapidana anak yang didik di LPKA Banda Aceh, dari 23 Anak ini mempunyai umur yang berbeda-beda, dengan perbedaan umur di antara mereka tentunya memerlukan hak rekreasional yang berbeda-beda juga, namun selama ini hak rekreasional yang di berikan di samaratakan, kehadiran LPKA ini diharapkan dapat memberikan hakhak anak yang ada di dalam menjalani masa pidananya, salah satunya yaitu hak rekreasional anak dan hak diperlakukan sebagaimana kebutuhannya. Sebagaimana yang disebutkan dalam Pasal 3 huruf a yaitu anak berhak diperlakukan secara manusiawi dengan memperhatikan kebutuhan sesuai dengan umurnya. Pasal 3 huruf d yaitu disebutkan anak berhak melakukan kegiatan rekreasional. Walaupun dirinya sedang menjalani masa hukuman penjara namun anak tetap harus dipenuhi haknya sesuai dengan aturan dalam undang-undang. LPKA Banda Aceh bertanggungjawab memberikan hak-hak kepada anak yang sedang menjalani masa hukumannya.

${ }^{12}$ M. Nasir Djamil, Anak Bukan Untuk Dihukum (catatan pembahasan UU sistemperadilan pidana anak-UU-SPPA) (Sinar Grafika 2013).[17]. 
Terkait dengan tugas LPKA, disebutkan secara tegas dalam Pasal 3 yaitu: LPKA mempunyai tugas melaksanakan pembinaan anak didik pemasyarakatan. Melalui pasal ini, dapat diketahui bahwa LPKA memiliki tugas pokok berupa pembinaan anak. Ini menandakan bahwa ada perlakuan khusus antara perbuatan pidana yang dilakukan anak dengan orang dewasa. Perlakuan khusus dimaksud berupa penanganannya tidak merupakan penghukuman atau pertanggung jawaban pidana. ${ }^{13}$

Hasil wawancara dengan Kasi Adm. Pengawasan dan Penegakan Disiplin LPKA Banda Aceh menjelaskan bahwa "pemberian hak rekreasional seperti yang dimaksudkan dalam pasal 3 Undang-Undang Nomor 11 Tahun 2012 tentang sistem peradilan pidana anak selama ini telah dilakukan di LPKA Banda Aceh, yang dimaksudkan kegiatan rekreasional ini adalah berupa pemberian kegiatan olahraga di dalam LPKA serta juga di berikan kegiatan yang lain berupa bermain musik".

Hasil wawancara dengan Susiyanti, A.Md Kasi Adm. Pengawasan dan Penegakan Disiplin LPKA Banda Aceh menjelaskan bahwa “Di dalam LPKA anakanak binaan diberikan pendidikan dari senin sampai kamis, jumat kita fokuskan untuk beribadah, kemudian baru pada hari sabtu dan minggu mereka melakukan kegiatan rekreasional, sengaja memang kita fokuskan pada sabtu dan minggu agar anak-anak focus belajar dari senin sampai kamis. Kegiatan olahraga yang dimaksud tadi itu meliputi bermain bola volley dan bermain music di dalam LPKA".

"Selama ini pemberian hak rekreasional ini dilakukan hanya di dalam LPKA saja, kemudian untuk kegiatan rekreasional itu dilakukan secara bergilir, mereka punya jadwal masing-masing agar tidak rebutan alat seperti saat main music, selama ini kegiatan rekreasional ini hanya di fokuskan di dalam LPKA, hal ini juga dikarenakan karena sedang adanya pandemic virus corona, sehingga untuk membawa anak-anak keluar itu sangat sulit, bahkan dulu saja sebelum ada corona untuk membawa anak-anak keluar untuk kegiatan rekreasional sangatlah sulit, banyak hal yang menjadi pertimbangan sehingga anak-anak tetap hanya bisa melakukan hak rekreasional dari dalam LPKA".

${ }^{13}$ Muladi dan Dwidja Priyatno, Pertanggungjawaban Pidana Koorporasi (Kencana Prenada Media Group 2013).[78]. 
Hasil wawancara Ria Munanda AnakDidik di LPKA Banda Aceh menjelaskan bahwa "selama ini hak rekreasinal yang mereka dapatkan hanyalah di dalam saja kebanyakanya, jikapun pernah di bawa keluar itupun hanya sebagai tamu dari undangan pihak luar seperti menjadi tamu undangan dari pihak"Kampus Universitas Syiah Kuala dan Universitas Islam Negeri Ar-Raniry,"sangat jarang mereka dibawah khusus ke laut atau ke wahana bermain".

"Selama ini tempat bermain yang ada di LPKA sangatlah sedikit, hanya bisa bermain volley dan badminton, dengan dua jenis permainan yang bisa dimainkan tentunya membuat kami disini sangat bosan, kami mengharapkan kedepanya ada permainan lain yang ada di LPKA Banda Aceh, apalagi sedang pandemi virus corona seperti ini mereka juga sangat susah bertemu dengan orangtua, sehingga kehadiran banyak tempat bermain sangatlah membantu untuk mengatasi kebosanan selama di dalam LPKA".

Kemudian hasil wawancara dengan Miki Syahputra Anak Didik di LPKA Banda Aceh menjelaskan "bahwa mereka sangat ingin melakukan kegiatan rekreasional di luar LPKA, kalau hanya di dalam LPKA sudah sangat membosankan karena hanya kegiatan itu-itu saja yang bisa mereka lakukan, mereka juga sangat ingin sesekali melihat suasana diluar bagaimana, miki dan anak didik lainnya sangat ini melakukan kegiatan rekreasional itu di laut atau tempat wahana bermain seperti di waterboom ataupun funlan. Seharusnya tempat bermain kami di LPKA di tambah lagi, seperti adanya lapangan futsal dan lapangan basket, jika ada tambahan tempat bermain yang lain ini sehingga bisa membuat kami tidak terlalu bosan selama di LPKA ini".

Hasil wawancara Jauhar Nafis Anak Didik di LPKA Banda Aceh menjelaskan “bahwa selama ini mereka sudah sangat bosan selama berada di dalam LPKA Banda Aceh, kegiatan yang bisa dilakukan sangatlah menoton, dirinya berharap setelah pandemic virus corona ini pihak LPKA bisa membawa dirinya dan temanteman jalan-jalan untuk melihat dunia luar dan bermain di tempat wahana yang ada di Kota Banda Aceh". 
Hasil wawancara dengan Irma Arianti ibu dari Ria Munanda Anak Didik LPKA Banda Aceh menjelaskan bahwa "selama ini anaknya selalu mengaku bosan berada di LPKA karena kegiatan rekreasional yang dilakukan hanyalah dengan cara bermain musik dan olahraga bermain volley, anaknya sangat rindu dengan dirinya, apalagi selama pandemic ini tidak bisa bertemu dengan sang anak, dirinya berharap kepada pihak LPKA untuk menambahkan tempat bermain atau bahkan jika memungkinkan anaknya dan anak-anak yang lain di LPKA tersebut di berikan hak rekreasional berupa jalan-jalan dan bermain di wahana bermain".

Hasil wawancara dengan Kasubsie Pendidikan dan Bimkemas LPKA Banda Aceh menjelaskan bahwa selama ini pemberian hak rekreasinal yang di maksud seperti dalam Pasal 3 Undang-Undang Nomor 11 Tahun 2012 tentang sistem peradilan pidana anak, di LPKA Banda Aceh pemberian hak rekreasional itu lebih banyak dilakukan di dalam LPKA sangat jarang dilakukan keluar dari LPKA.

Pemberian hak rekreasional di dalam LPKA memang belum maksimal, karena selama ini hanya sebatas pemberian bermain volley dan bermain alat musik, memang ada dilakukan bedah buku ataupun diskusi-diskusi maupun nonton bersama namun hanya beberapa kali dan itupun jika ada pihak luar dari LPKA seperti dari"Universitas Syiah Kuala dan Universitas Islam Negeri ArRaniry," pernah beberapa kali para anak didik ini di bawa keluar LPKA sebagai tamu undangan, sangat jarang di lakukan kegiatan yang dikhususkan untuk pemeberian hak untuk melakukan rekreasional bagi anak.

Hasil wawancara dengan Dosen Fakultas Psikologi Universitas Syiah Kuala Afriani, S.Psi., M.Sc menjelaskan bahwa "pemberian hak rekreasional kepada anak-anak didik di LPKA ini berdasarkan pada asas pendidikan, bahwa di dalam LPKA anak didik mendapat pendidikan, hal ini adalah hak yang harus di penuhi oleh LPKA kepada anak didik, kemudian adanya" asas penghormatan Harkat dan Martabat manusia, anak didik di LPKA tetap diberlakukan sebagai manusia dengan menghormati harkat dan martabatnya".

Dalam pemberian hak rekreasional ini menjadi sangat penting dikarenakan dalam tumbuh dan berkembangya seorang anak memiliki tahun-tahun yang 
mempunyai arti penting bagi anak tersebut, anak-anak di LPKA ini adalah mereka yang mempunyai umur transisi untuk menjadi remaja, dalam hal ini pendidikan dan rekreasional sangatlah penting bagi mereka, pendidikan untuk mendapatkan ilmu sedangkan rekreasional agar mereka tidak penat selama menjalani masa pembinaan di LPKA.

Pendidikan dan Rekreasional ini harusnya berjalan sebanding atau sama cukupnya dalam pemberian di LPKA, walaupun meraka menjadi narapidana anak namun hal hal pokok seperti hak pendidikan dan rekreasional harus tetap diberikan, berbeda dengan narapidana dewasa, yang tidak terlalu memerlukan lagi hak rekreasional, anak-anak ini secara psikologis masih lemah pemikiranya menangung beban selama di LPKA, karena tidak bisa bebas seperti anak-anak lain diluar.

Umur anak didik di LPKA ini rata-rata umur yang menjelang remaja, di dalam masa ini para anak didik akan mempunyai emosi yang berbeda-beda, dan juga mempunyai bakat yang berbeda-beda, bakat seseorang bisa dilihat dari umurumur ini, sehingga pemberian hak rekreasional di dalam LPKA juga ada diatur karena memperhatikan hal tersebut. Anak-anak di umur ini juga mempunyai tingkah laku yang unik, yaitu ada yang jadi pribadi yang baik dan ada juga jadi pribadi yang nakal, sehingga dengan pemunuhan hak rekeasi dan hak pendidikan akan membawa mereka kearah yang baik.

Pemberian hak rekreasional ini menjadi sangat penting saat ini, dikarenakan para anak didik adalah anak-anak yang memikiki usia potensial dan di usiausia inilah kita bisa melihat bakat mereka, jika tidak didukung dengan fasilitas di LPKA dalam pemberian hak rekreasional ini maka bakat-bakat tersebut tidak bermunculan, kemudian juga mereka ini berbeda dengan narapidana dewasa, narapidana anak ini masih banyak membutuhkan pendidikan dan rekreasional belum sanggup menerima banyak beban, sehingga sangat penting dilakukan pemberian hak pendidikan dan rekreasional anak di LPKA.

Anak didik di Lembaga Pembinaan Khusus Anak (LPKA) walaupun sudah menjadi narapidana tetap harus mendapatkan hak-haknya di LPKA dikarenakan 
ini merupakan hak yang harus mereka dapatkan karena hukum telah mengatur mengenai hal tersebut termasuk hak melakukan kegiatan rekreasional, kemudian hak rekreasional ini juga merupakan Hak Asasi Manusia. Hak Asasi Manusia adalah hak-hak yang diberikan langsung oleh Tuhan Yang Maha Pencipta (hakhak yang bersifat kodrati). Oleh karena itu, tidak ada kekuasaan apapun di dunia yang dapat mencabutnya.

Di Indonesia, hak asasi manusia tidak dapat dipisahkan dengan pandangan filosofis bangsa Indonesia yang terkandung dalam Pancasila, bahwa hakekat manusia adalah monopluralis. Susunan kodrat manusia adalah jasmani dan rohani yang sifat dan kodratnya manusia adalah makhluk individu dan makhluk sosial serta berkedudukan kodrat sebagai makhluk pribadi yang berdiri sendiri dan sebagai makhluk Tuhan Yang Maha Esa. Berdasarkan tujuan negara yang diatur dalam Undang-Undang Dasar Negara Republik Indonesia Tahun 1945 menyebutkan bahwa negara Indonesia menjamin dan melindungi hak-hak asasi manusia para warganya, terutama berkaitan dengan kesejahteraan hidupnya baik jasmaniah maupun rohaniah, antara lain berkaitan dengan hak-hak asasi bidang sosial, politik, ekonomi dan kebudayaan, pendidikan dan agama, yang rinciannya dimuat dalam Bab XA tentang Hak Asasi Manusia. ${ }^{14}$

Beberapa konsep keadilan"yang dikemukakan oleh Filsuf Amerika di akhir abad ke-20, John Rawls, seperi A Theory of justice, Politcal Liberalism, dan The Law of Peoples, yang memberikan pengaruh pemikiran cukup besar terhadap diskursus nilai-nilai keadilan. John Rawls yang dipandang sebagai perspektif "liberalegalitarian of social justice", berpendapat bahwa"keadilan adalah kebajikan utama dari hadirnya institusi-institusi sosial (social institutions). Akan tetapi, kebajikan bagi seluruh masyarakat tidak dapat mengesampingkan atau menggugat rasa keadilan dari setiap orang yang telah memperoleh rasa keadilan. Khususnya masyarakat lemah pencari keadilan. ${ }^{15}$ 2016).[10]

${ }^{14}$ Abintoro Prakoso, Pembaharuan Sistem Peradilan Pidana Anak Edisi Revisi (Aswaja Pressindo ${ }^{15}$ Pan Mohamad Faiz, 'Teori Keadilan John Rawls' (2009) 6 (1) Jurnal Konstitusi.[139]. 
Zulyani Mahmud, dkk: Pemenuhan Hak Rekreasional...

Hak Asasi Manusia (selanjutnya disingkat HAM) merupakan hak-hak yang melekat pada manusia yang mencerminkan martabatnya, yang harus memperoleh jaminan hukum, sebab hak-hak hanya dapat efektif apabila hak-hak itu dapat dilindungi hukum. Hans Kelsen dalam bukunya general theory of law and state, berpandangan bahwa hukum sebagai tatanan sosial yang dapat dinyatakan adil apabila dapat mengatur perbuatan manusia dengan cara yang memuaskan sehingga dapat menemukan kebahagian didalamnya. Pandangan Hans Kelsen ini pandangan yang bersifat positifisme, nilai-nilai keadilan individu dapat diketahui dengan aturan-aturan hukum yang mengakomodir nilai-nialai umum, namun tetap pemenuhan rasa keadilan dan kebahagian diperuntukan tiap individu. ${ }^{16}$

Dalam pemberian hak rekreasional kepada anak didik di Lembaga Pembinaan Khusus Anak (LPKA) ini juga harus didasarkan pada teori keadian,yaitu pemberian hak rekreasional tidak boleh disamaratakan namun haruslah di sesuaikan berdasakan umur anak didik, anak didik yang umurnya berbeda-beda juga membutuhkan rekreasional yang berbeda-beda pula.

Faktor Pendukung dan Penghambat yang Dihadapi Lembaga Pembinaan Khusus Anak Kota Banda Aceh dalam Hal Pemenuhan Hak Rekresional Anak

\section{a. Faktor Pendukung}

Pemberian hak rekeasional selama ini bisa dilakukan dengan cara memberikan mereka kebebasan bermain di dalam LPKA, bermain yang bisa dilakukan selama di LPKA adalah bermain volley dan bermain musik, mereka juga sering melakukan kegiatan-kegiatan seperti bedah buku dari teman-teman mahasiswa yang membuat kegiatan di LPKA, di dalam kegiatan tersebut biasanya teman-teman mahasiswa melakukanya dengan mengisi sesi game di tengah kegiatan, hal-hal itulah yang membuat anak-anak didik di LPKA bisa mendapatkan kegiatan rekreasional di dalam LPKA. Selama ini pemberian hak rekreasional untuk faktor pendukungnya hanya dari pihak luar, karena untuk saat ini belum

${ }^{16}$ Hans Kelsen, General Theory of Law and State (Nusa Media 2011).[7]. 
ada rencana pemberian hak rekreasional kepada anak-anak didik di LPKA untuk di bawa keluar dari LPKA. Kegiatan-kegiatan yang di lakukan di LPKA oleh pihak luar sangat membantu membuat anak didik di LPKA menghilangkan kebosanan mereka disini

\section{b. Faktor Penghambat}

Pemberian hak rekreasional kepada anak didik ini tidak di atur khusus di dalam LPKA, selama ini LPKA Banda Aceh dalam hal pemberian hak rekreasional kepada anak-anak didik hanya ada di dalam LPKA saja, dan itupun lebih kepada kegiatan olahraga yang dilakukan, tidak ada kegiatan khusus yang di lakukan oleh pihak LPKA dalam hal pemberian Hak Rekreasional kepada anak-anak didik di LPKA. Pemberian hak rekreasional juga mendapat hambatan dikarenakan selama ini LPKA tidak memiliki anggaran untuk pemberian kegiatan rekreasional, maka dari itu sangat sulit untuk membawa anak didik mendapatkan rekreasi di luar, pada setiap awal tahun itu memang tidak ada sama sekali anggaran untuk kegiatan rekreasional tersebut, hal inilah yang mengakibatkan hak rekreasional dilakukan kapan sempat saja atau saat ada undangan saja.

Selama ini memang tidak ada anggaran khusus baik dari LPKA ataupun Direktur Jenderal Pemasyarakatan serta Kementrian Hukum dan Ham untuk pemberian hak rekreasional ini, tidak adanya anggaran ini dikarenakan memang tidak ada dana yang disiapkan untuk pemberian hak rekreasional ini, karena memang dari pusat (Dirjen Pas) tidak mengalokasikan dana untuk pemberian hak rekreasional, jadi jika memang bisa dilakukan pemberian hak rekreasional di luar itu memang harus berdasarkan kebijakan dari pimpinan LPKA, ada beberapa kali memang anak didik dibawa keluar dari LPKA tapi tidak semua, harus bergilir hal ini dikarenakan karena kurangnya anggota dari kami, sehingga tidak memungkinkan membawa semuanya.

Dalam halnya kurangnya anggota dari pihak LPKA menjadi faktor penghambat pemberian hak rekreasional kepada anak didik di LPKA menjadi keliru, dikarenakan para anggota di LKPA lebih banyak dari anak didik, bahkan mencapai 45 Anggota, sehingga dengan anggota yang banyak tersebut pemberian 
hak rekreasional kepada anak dapat lebih maksimal. Pemberian hak rekreasional di luar LPKA juga sangat beresiko, karena anak-anak didik sangat memungkinkan untuk lari dikarnekan mereka sudah sangat bosan menjalani masa hukuman, jadi selalu ada niat lari dari setiap anak didik di LPKA, Bahkan dulu pernah ada seorang anak didik yang mencoba lari ketika dibawa kabur ketika di bawa keluar dari LPKA, selama ini memang tempat bermain bagi anak-anak didik sangatlah sedikit, jadi sangat wajar mereka bosan selama di LPKA ini.

Dalam terjadinya faktor penghambat terhadap pemberian hak rekreasional kepada maka dapat di kaitkan dengan teori hukum efektivitas hukum, dalam hal ini hukum yang sudah diatur tentang pemberian hak rekreasional kepada anak didik di LPKA, namun dalam pelaksanaanya pemunuhan tersebut belum maksimal, jika kita lihat dari efektivitas hukum, aturan mengenai pemberian hak rekreasional ini belum efektif, karena tidak mengatur secara tegas bagaimana seharusnya hak rekreasional itu dilakukan.

\section{Upaya yang Dilakukan oleh Lembaga Pembinaan Khusus Anak Kota Banda Aceh dalam Pemenuhan Hak Rekreasional Anak}

Lembaga Pembinaan Khusus Anak merupakan unit pelaksana teknis yang berkedudukan di bawah dan bertanggung jawab kepada Direktur Jenderal Pemasyarakatan yang dipimpin oleh seorang kepala. Dengan terkait dengan tugas dan fungsi LPKA Banda Aceh, mengikuti tugas dan fungsi yang ditetapkan dalam Peraturan Menteri Hukum dan Hak Asasi Manusia Nomor 18 Tahun 2015 tentang Organisasi dan Tata Kerja Lembaga Pembinaan Khusus Anak. Artinya, LPKA yang ada di seluruh wilayah Indonesia merujuk pada peraturan tersebut sebagai dasar hukum pelaksanaan tupoksi LPKA.

Terkait dengan tugas LPKA, disebutkan secara tegas dalam Pasal 3 yaitu: LPKA mempunyai tugas melaksanakan pembinaan anak didik pemasyarakatan. Melalui pasal ini, dapat diketahui bahwa LPKA memiliki tugas pokok berupa pembinaan anak. Ini menandakan bahwa ada perlakuan khusus antara perbuatan pidana yang dilakukan anak dengan orang dewasa. Perlakuan khusus dimaksud 
berupa penanganannya tidak merupakan penghukuman atau pertanggung jawaban pidana, melainkan pembinaan. Hal ini tentu berbeda dengan pelaku dewasa yang upaya penanganan hukumnya berupa pertanggungjawaban pidana. Pertanggungjawaban pidana yang dimaksudkan di sini adalah hubungan batin antara si pelaku pidana dengan perbuatannya sehingga ia dinyatakan sadar melakukan tindakan itu, hingga dapat dibebani hukum. Dalam makna lain, pertanggungjawaban pidana adalah mengenakan celaan (hukuman) terhadap pembuat karena perbuatannya yang melanggar larangan atau menimbulkan keadaan yang terlarang.

Dalam hal memberikan hak-hak anak didik di LPKA Banda Aceh telah melakukan beberapa upaya, dalam hal khusus pemberian hak rekreasional, LPKA selalu menerima kerjasama dari pihak luar yang dinilai bisa memberikan kegiatan yang bermanfaat kepada para anak didik di LPKA, Seperti bekerja sama dengan Mahasiswa/i dari berbagai Universitas yang ada di Aceh maupun di Indonesia, karena dengan kerjamasa dengan membuat kegiatan di LPKA ini dapat memberikan pengetahuan baru tentunya juga menghilangkan kebosanan dari anak didik di dalam LPKA.

Upaya yang dilakukan juga dengan cara memperbanyak pemberian jam bermain bagi anak didik, dengan cara memfokuskan di dua hari yaitu hari sabtu dan minggu, upaya ini dirasakan dapat membuat anak mendapatkan hak rekreasionalnya selama di dalam LPKA, setelah belajar dari hari senin sampai kamis, jumat di isi dengan kegiatan beribadah maka sabtu dan minggu di isi dengan bermain olahraga dan bermain musik. Selama ini pihak LPKA sudah pernah memberikan usulan kepada Direktur Jenderal Pemasyarakatan serta kepada Kementrian Hukum dan Ham mengenai fasilitas untuk rekreasional ankanak di dalam LPKA sangatlah kurang, mereka sudah pernah mengusulkan untuk penambahan lapangan futsal, lapangan basket, namun sampai saat ini usulan tersebut tidak mendapatkan respon, dengan fasilitas yang ada sekarang memang sangat sedikit sehingga wajar anak-anak didik merasakan kebosanan selama berada di dalam LPKA. 
Zulyani Mahmud, dkk: Pemenuhan Hak Rekreasional...

LPKA Banda Aceh juga pernah membahas hal anggaran untuk hak rekreasional anak dengan Direktur Jenderal Pemasyarakatan dan Kementrian Hukum dan Hak Asasi Manusia, dengan adanya plot anggaran untuk hak rekreasional ini akan memudahkan dalam hal pemeberian hak rekreasional kepada anak didik, selama ini terkendala dalam pemberian hak rekreasional juga dikarenakan tidak ada dana khusus yang di fokuskan untuk pemberian hak rekreasional terhadap anak Agar lebih maksimal dalam pemberian hak rekreasional seharusnya di awal tahun di atur dalam agenda atau kegiatan tetap LPKA mengenai pemberian hak rekreasional kepada anak didik ini, misalnya dalam setahun diberikan 3 kali kegiatan untuk rekreasional ini, jika sudah di dukung dengan dana yang sudah disiapkan untuk pemberian hak rekreasional dan sudah di jadwalkan makan pemberian hak rekreasional akan tercipta dengan maksimal sesuai yang diamanahkan oleh Undang- Undang Nomor 11 Tahun 2012 tentang sistem peradilan pidana anak

Upaya-upaya yang dilakukan ini juga berujuan untuk mencapai keadlian dan perlindungan hukum kepada anak-anak di LPKA, hal ini harus sesuai yang dimaksudkan dalam teori keadilan dan teori perlindungan hukum, para anak didik di LPKA mempunyai hak dan kewajiban, keduanya harus dipenuhi dan dilindungi oleh LPKA, kemudian keadilan kepada anak didik di LPKA juga harus diberikan sebaik mugkin, pemberian hak rekereasional tidak bisa disamaratakan tetapi harus tepat sasaran, harus disesuaikan berdasarkan usia masing-masing anak didik di LPKA, kemudian juga pemberian rekreasional harus beragam.

\section{Kesimpulan}

Pemberian Hak Rekreasional terhadap anak di LPKA Banda Aceh belum berjalan maksimal, tidak diatur secara jelas mekanisme pemberian hak rekreasional, tidak ada anggaran khusus untuk pemberian hak rekreasional untuk anak didik di LPKA, selama ini pemberian hak rekreasional hanya atas dasar kebijakan Kepala LPKA. pemberian hak rekreasional dilakukan dari dalam LPKA dan dari luar LPKA, dari dalam LPKA dilakukan dengan cara memberikan jadwal bermain 
kepada anak didik di hari sabtu dan minggu, kegiatan yang dilakukan adalah bermain volley dan bermain alat musik, kegiatan di luar LPKA yaitu menjadi tamu pada acara-acara diskusi maupun bedah buku yang diselenggarkan oleh pihak lain, tidak ada kegiatan khusus yang dilaksanakan untuk memberikan hak rekreasional kepada anak didik di LPKA.

Faktor Pendukung dalam hal pemberian hak rekreasional kepada anak yaitu tempat bermain di LPKA seperti adanya lapangan volley dan tersedianya alat musik, dukungan dari pihak luar seperti dari"Universitas Syiah Kuala dan Universitas Islam Negeri Ar-Raniry."Faktor Penghambat dalam pemberian hak rekreasional adalah tidak adanya anggaran khusus yang di fokuskan untuk pemberian hak rekreasional kepada anak di LPKA Banda Aceh, tidak diagendakan secara khusus pemberian hak rekreasional anak didik di luar LPKA, selama ini hanya difokuskan di dalam LPKA, Pemberian hak rekreasional di luar LPKA sangat beresiko.

Upaya yang dilakukan oleh LPKA Banda Aceh dalam hal pemberian hak rekreasional kepada anak adalah dengan cara mengusulkan kepada Direktur Jenderal Pemasyarakatan serta kepada Kementrian Hukum dan Ham untuk melakukan penambahan tempat bermain kepada anak didik di LPKA serta memperbanyak kegiatan di LPKA yang menghasilkan pemberian hak rekreasional kepada anak didik di LPKA, mengagendakan secara khusus pemberian hak rekreasional kepada anak didik di LPKA di setiap tahunnya. Mengusulkan agar adanya anggaran khusus untuk pemberian hak rekreasional kepada anak didik di luar LPKA.

\section{Daftar Bacaan}

\section{Buku}

Abintoro Prakoso, Pembaharuan Sistem Peradilan Pidana Anak Edisi Revisi (Aswaja Pressindo 2016).

Agus Yudha Hernoko, Asas Proporsionalitas dalam Kontrak Komersial (Laksbang Mediatama 2008). 
Zulyani Mahmud, dkk: Pemenuhan Hak Rekreasional...

Hans Kelsen, General Theory of Law and State (Nusa Media 2011).

Lilik Mulyadi, Wajah Sistem Peradilan Pidana Indonesia (PT Alumni 2014).

M. Nasir Djamil, Anak Bukan Untuk Dihukum(catatan pembahasan UU sistemperadilan pidana anak-UU-SPPA) (Sinar Grafika 2013).

Muladi dan Dwidja Priyatno, Pertanggungjawaban Pidana Koorporasi (Kencana Prenada Media Group 2013).

R.Wiyono, Sistem Peradilan Pidana Anak di Indonesia (Sinar Grafika 2019).

Sri Sutatiek, (2013), Rekonstruksi Sistem Sanksi Dalam Hukum Pidana Anak Di Indonesia (AswajaPressindo 2013).

Wagiati soetedjo dan Melani, Hukum Pidana Anak (PT. Refika Aditama 2017).

\section{Jurnal}

Hartono Hartono, 'Konsep Pembinaan Anak Dalam Lembaga Pembinaan Khusus Anak (LPKA) Dalam Perspektif Hak Asasi Manusia' (2019) 11 (1) YURJSKA Jurnal Ilmiah Hukum.

Budijanto, 'Pemenuhan Hak Pendidikan Bagi Anak Didik Pemasyarakatan Di Lembaga Pembinaan Khusus Anak' (2013) 7 (1) Jurnal Ilmiah Kebijakan Hukum.

Riska Wiraman dan Ida Hayu Dwimawanti, 'Kualitas Pelayanan Pendidikan Anak Binaan di Lembaga Pembinaan Khusus Anak (LPKA) Klas 1 Kutoarjo Kabupaten Purworejo' (2019) 1 (2) Jurnal Ilmu Administrasi Publik.

Moh Fauziddin dan Mufarizuddin, 'Useful Of Clap Hand Games For Optimalize Cogtivitie Aspects In Early Childhood Education.' (2018) 2 (2) Jurnal Obsesi: Jurnal Pendidikan Anak Usia Dini.

Lili halimah, 'Representasi Civic Disposition melalui Pendekatan Moral pada Anak Didik Pemasyarakatan di Lembaga Pembinaan Khusus Anak (LPKA) Sukamiskin Provinsi Jawa Barat' (2020) 5 (1) Jurnal Pancasila dan Kewarganegaraan (JPK).

Fransiska Novita Eleanora. (2018) ‘Tinjauan Yuridis Pembinaan Anak di Lembaga Pembinaan Khusus Anak (LPKA) Tangerang' (2018) 18 (3) Jurnal Kajian Ilmiah.

Pan Mohamad Faiz, 'Teori Keadilan John Rawls' (2009) 6 (1) Jurnal Konstitusi. 


\section{Perundang-undangan}

Undang-Undang Nomor 39 Tahun 1999 Tentang Hak Asasi Manusia.

Undang-Undang Nomor 11 Tahun 2012 Tentang Peradilan Pidana Anak.

Undang-Undang Nomor 35 Tahun 2014 Tentang Perlindungan Anak.

How to cite: Zulyani Mahmud, Zahratul Idami dan Suhaimi, 'Pemenuhan Hak Rekreasional Terhadap Narapidana Anak Di Lembaga Pembinaan Khusus Anak Banda Aceh' (2021) Vol. 4 No. 2 Media Iuris. 
--Halaman ini sengaja dibiarkan kosong-- 